\title{
BIOAKTIVITAS JAMUR Aspergillus flavus YANG BERSIMBION DENGAN ASCIDIAN Eudistoma sp.
}

\author{
(BIOACTIVITY OF MARINE DERIVED SYMBIOTIC FUNGUS Aspergillus flavus FROM \\ ASCIDIAN Eudistoma sp.)
}

\author{
Alfa Mongi ${ }^{1 *}$, Deiske A. Sumilat ${ }^{1}$, Fitje Losung ${ }^{1}$, Remy E.P. Mangindaan ${ }^{1}$, \\ Rosita A. J. Lintang ${ }^{1}$, Suzanne L. Undap ${ }^{2}$
}

${ }^{1}$ Program Studi IImu Kelautan, FPIK, UNSRAT

${ }^{2}$ Program Studi Budidaya Perairan, FPIK, UNSRAT

*E-mail : deiske.sumilat@gmail.com

\begin{abstract}
Ascidian is a marine invertebrate that produce bioactive compounds such as antibacterial and antifungal. The purpose of this study was to obtain symbiotic fungi isolates, ethyl acetate extracts from ascidian symbiotic isolates, and to determine the antibacterial and antifungal activities of ethyl acetate extracts of symbiotic isolates using the diffusion method (disc diffusion Kirby and Bauer) against Escherichia coli, Staphylococcus aureus bacteria and against the Candida albicans fungus. The results obtained 1 ascidian species which was cultured to obtain pure isolates, the pure isolates were tested molecularly and the results showed that the isolate was Aspergillus flavus, then the isolates were grown on rice medium and extracted. The results of the fungal extract showed the presence of antibacterial and antifungal activity against Escherichia coli by $10 \mathrm{~mm}$, Staphylococcus aureus by $19 \mathrm{~mm}$ and against the Candida albicans by $13.5 \mathrm{~mm}$.
\end{abstract}

Keywords : Ascidian, Eudistoma sp., Aspergillus flavus, Antibacterial, Antifungal, Symbiotic.

\begin{abstract}
Abstrak
Ascidian merupakan avertebrata laut yang dapat menghasilkan senyawa bioaktif yang seperti antibakteri dan antijamur. Tujuan dari penelitian ini yaitu mendapatkan isolat jamur simbion dari ascidian, mendapatkan ekstrak etil asetat dari isolat jamur simbion ascidian, dan menguji aktivitas antibakteri dan antijamur ekstrak etil asetat isolat jamur simbion dengan metode difusi agar (disc diffusion Kirby and Bauer) terhadap bakteri Escherichia coli, Staphylococcus aureus dan terhadap jamur Candida albicsans. Hasil penelitian didapatkan 1 jenis ascidian yang kemudian dikultur untuk mendapatkan isolat murni, isolat murni diuji secara molekuler dan didapati hasil bahwa isolat tersebut merupakan jamur Aspergillus flavus. Isolat tersebut kemudian ditumbuhkan pada media nasi dan diekstrak. Hasil ekstrak jamur tersebut menunjukkan adanya aktivitas antibakteri dan antijamur terhadap bakteri Escherichia coli sebesar $10 \mathrm{~mm}$, Staphylococcus aureus sebesar $19 \mathrm{~mm}$ dan terhadap jamur Candida albicsans 13,5 mm.
\end{abstract}

Kata kunci : Ascidian, Eudistoma sp., Aspergillus flavus, Antibakteri, Antijamur, Simbion. 


\section{PENDAHULUAN}

Secara geografis Indonesia memiliki wilayah perairan lebih luas dari daratan. Hal ini membuat perairan Indonesia memiliki keanekaragaman hayati laut yang tinggi yang seharusnya dapat dijadikan sebagai objek pengembangan dan penelitian, mengingat banyaknya sumber daya alam potensial yang belum sepenuhnya terkuak. Keanekaragaman organisme (biodiversity) laut juga mempunyai arti keanekaragaman senyawa kimia (chemodiversity) yang terkandung dalam organisme. Senyawasenyawa tersebut dapat memiliki aktivitas biologis yang bervariasi. Bahan alam laut berupa senyawa-senyawa kimia tersebut berpotensi dikembangkan sebagai bahan obat. Beberapa biota laut yang diketahui dapat menghasilkan bahan hayati yang memiliki aktivitas biologis di antaranya yaitu bryozoa, spons, moluska dan ascidian (Proksch et al., 2002).

Penelitian terhadap ascidian telah berkembang dengan baik, yang mengarah pada isolasi berbagai metabolit yang memiliki struktur yang unik dan senyawa bioaktivitas yang besar. Hal ini membuat ascidian memiliki potensi sebagai sumber obat-obatan alami untuk mengobati berbagai penyakit, produk yang dihasilkan seperti larvasida, sitotoksik, antijamur, antikanker, antiinflamasi, antivirus, dan antibakteri (Ali dan Tamilselvi, 2016; Donia et al., 2008; Wang et al., 2008; Rumengan, 2010; Chan et al., 2011; Macpal et al., 2019; Losung et al., 2015; Mangindaan dan Taroreh, 2013; Moerid et al., 2013; Opa et al., 2018; Wewengkang et al., 2014). Reddy et al. (2011), jumlah metabolit sekunder yang diisolasi dari jamur laut yang bersimbiosis dengan alga, sponge, ascidian, dan organisme lainnya sebagai antibakteri, antijamur, dan sitotoksik rata-rata $75 \%$ memiliki aktivitas biologis.

Sumilat et al., (2017), produk alami yang diperoleh dari organisme laut semakin mendapat perhatian karena substansi bioaktif yang terkandung di dalamnya berpotensi untuk dapat dijadikan sebagai bahan obat-obatan. Oleh sebab itu, eksplorasi jamur simbion dari ascidian perlu dilakukan. Selain itu, berbagai penyakit yang disebabkan oleh bakteri dan jamur pada saat ini semakin banyak dan diperlukan pencarian senyawa antibakteri dan antijamur yang baru.

Adapun dalam penelitian ini pengujian antibakteri dan anti jamur menggunakan mikroba uji yaitu bakteri Escherichia coli, Staphylococcus aureus dan jamur Candida albicans. E. coli merupakan bakteri gram negatif yang ditemukan dalam saluran pencernaan hewan dan manusia (Melliawatri, 2009). S. aureus merupakan bakteri gram positif bakteri yang pada manusia bakteri ini bersifat pathogen (Warsa, 1994). Sendangkan jamur $C$. albicans merupakan jamur yang kandidiasis atau kandidosis yaitu suatu penyakit jamur yang bersifat akut dan sub-akut yang dapat mengenai mulut, vagina, kulit, kuku, paruparu dan saluran pencernaan (Jawetz et al., 2016).

Lokasi penelitian Perairan Pangalingsang Bunaken Sulawesi Utara memiliki alam bawah laut yang begitu kaya akan keanekaraganaman hayati sehingga perlu dilakukan eksplorasi dan eksploitasi terhadap metabolit sekunder yang dihasilkan oleh ascidian, dalam penelitian ini organisme ascidian diisolasi untuk mendapatkan isolat jamur simbion, selanjutnya jamur simbion tersebut dikultur pada media nasi dan diekstraksi untuk diuji aktivitas antibakteri dan antijamur dengan menggunakan metode difusi agar.

\section{METODE PENELITIAN}

\section{Waktu dan Tempat Penelitian}

Tempat pengambilan sampel pada Perairan Pangalisang Bunaken, kemudian penelitian dilanjutkan di Laboratorium Biologi Molekuler dan Farmasitika Laut, FPIK UNSRAT untuk kegiatan isolasi sampel, kultur jamur, ekstraksi, serta pengujian aktivitas antibakteri dan anti jamur. 


\section{Pengambilan Sampel Ascidian}

Sampel ascidian diperoleh dari perairan Pangalisang Bunaken dengan cara menyelam (diver) dengan menggunakan 1 set alat snorkeling (skin diver) pada kedalaman \pm 3-7 meter.

Sampel diambil dengan cara memotong organisme ascidian langsung dari substratnya, kemudian sampel dimasukkan ke dalam plastik sampel bersih. Sampel selanjutnya dibawa ke Laboratorium Biologi Molekuler dan Farmasetika Laut Fakultas Perikanan dan IImu Kelautan UNSRAT.

\section{Media Potato Dextrose Agar (PDA)}

Media PDA adalah media untuk menumbuhkan jamur. Media PDA 3,9 gram, dimasukkan dalam labu erlenmeyer dan dilarutkan dalam air laut saring sebanyak $100 \mathrm{ml}$. Media disterilkan dengan di dalam autoklaf pada suhu $121^{\circ} \mathrm{C}$ selama \pm 20 menit, kemudian diaduk dengan cara menggoyangkan dengan cara perlahan dan dituang ke dalam cawan petri.

\section{Isolasi Jamur Yang Bersimbion Dengan Ascidian}

Sampel diisolasi dengan cara ditanam pada media padat PDA yang sudah disiapkan sebelumnya. Inokulasi dilakukan di dalam Laminary Air Flow dengan cara sampel ascidian dipotong kecil-kecil menggunakan pisau steril dan ditanam ke dalam cawan petri dengan menggunakan pinset steril. Cawan petri dibungkus dengan menggunakan lakban kertas (masking tape) dan diinkubasi pada suhu ruangan selama $3 \times 24$ jam.

Setelah 3×24 jam, maka akan didapati jamur yang mulai bertumbuh di sekitaran sampel ascidian. Jamur-jamur tersebut kemudian dipurifikasi. Kegiatan purifikasi dilakukan di dalam Laminary Air Flow dengan cara mengambil jamur yang tumbuh pada ascidian dengan pisau dan jarum ose yang telah dibakar pada lampu bunsen, kemudian ditanam pada media PDA yang baru, kegiatan ini dilakukan beberapa kali dengan cara yang sama.

\section{Pembuatan Media Nasi}

Media nasi dibuat dengan mengunakan beras (superwin). Beras sebanyak 50 gram dimasukkan ke dalam labu erlemeyer, dan tambahkan air laut saring sebanyak $60 \mathrm{ml}$., ditutup dan dibungkus dengan alumunium foil kemudian dimasak- steril dengan autoklaf pada suhu $121^{\circ} \mathrm{C}$ selama \pm 20 menit. Setelah itu media nasi diinkubasi pada suhu ruangan selama 5x24 jam (Kjer et al., 2010).

\section{Kultur Isolat Murni Jamur Simbion di Media Nasi}

Ketika jamur yang dikultur pada media PDA sudah homogen, dipotong berbentuk kubus dan dipindahkan ke dalam labu Erlenmeyer yang mengandung media nasi kemudian ditutup dengan kapas. Media nasi diinkubasi pada suhu ruangan selama 14x24 jam (Kjer et al., 2010).

\section{Ekstraksi Jamur Simbion Dari Ascidian Dengan Etil Asetat}

Ekstraksi jamur simbion dari ascidian dilakukan berdasarkan metode ekstraksi yang mengacu pada metode Kjer et al., (2010), dengan beberapa modifikasi. Jamur yang sudah bertumbuh di media nasi dihancurkan terlebih dahulu dengan menggunakan pengaduk kaca, kemudian dimaserasi menggunakan pelarut etil asetat sebanyak 3x $100 \mathrm{ml}$. Hasil maserasi dievaporasi menggunakan rotary vacuum evaporator pada suhu $40^{\circ} \mathrm{C}$ hingga diperoleh ekstrak etil asetat.

\section{Pengujian Antibakteri dan Antijamur Ekstrak Kasar Jamur Simbion Fraksi Etil Asetat}

\section{Sterilisasi Alat dan Media}

Sterilisasi alat-alat dan media yang digunakan pada pengujian antibakteri ini seperti cawan petri, gelas erlenmeyer, dan tabung reaksi semuanya dicuci bersih, 
dikeringkan dan dibungkus dengan kertas lalu dimasukkan ke dalam oven pada suhu $160^{\circ} \mathrm{C}$ selama kurang lebih 2 jam (sterilisasi kering). Sedangkan untuk alat lainnya seperti tip mikropipet yang berada dalam kotak plastik steril, langsung dibungkus dengan alumunium foil.

\section{Pembuatan Media cair B1}

Media cair B1 dibuat untuk mengkultur mikroba uji. Pepton $0,5 \mathrm{~g}$, beef extract $0,3 \mathrm{~g}$, natrium klorida $0,3 \mathrm{~g}$ dan akuades sebanyak $100 \mathrm{ml}$ diaduk sampai homogen kemudian disterilkan dalam autoklaf pada suhu $121^{\circ} \mathrm{C}$ selama 15 menit dan setelah itu didinginkan. Setelah dingin, media cair B1 ditutup dengan aluminium foil dan diinkubasi pada suhu ruangan selama 1×24 jam.

\section{Kultur Mikroba Uji}

Mikroba yang digunakan yaitu E. coli, $S$. aureus dan $C$. albicans. E. coli dan $S$. aureus diambil dengan menggunakan jarum ose steril dan dimasukkan ke dalam erlenmeyer yang berisi media cair B1. Sedangkan $C$. albicans diambil dari biakan murni menggunakan mikropipet sebanyak $100 \mu \mathrm{L}$ dan dimasukkan ke dalam erlenmeyer yang sudah berisi media cair B1 sebanyak $1 \mathrm{ml}$ dan kemudian ditutup menggunakan aluminium foil. Setelah itu, diinkubasi pada suhu ruangan selama $1 \times 24$ jam.

\section{Pembuatan Media Uji}

Media uji yang digunakan yaitu media B1 (padat) dengan komposisi pepton 0,5 g, beef extract 0,3 g, natrium klorida 0,3 g, agar1,5 dan akuades sebanyak $100 \mathrm{ml}$. Setelah itu ditutup dan dibungkus dengan kertas aluminium foil lalu media uji tersebut diaduk sampai homogen kemudian disterilkan dalam autoklaf pada suhu $121^{\circ} \mathrm{C}$ selama 15 menit. Selanjutnya media ditunggu sampai hangat lalu masukkan mikroba yang telah dikultur pada media cair B1 menggunakan mikropipet berukuran $1000 \mu \mathrm{l}$ kemudian ditutup kembali menggunakan alumunium foil dan diaduk dengan perlahan, dan dituang ke dalam cawan petri steril.

\section{Kontrol Positif Dan Kontrol Negatif}

Uji aktivitas antibakteri, menggunakan kontrol positif yaitu $250 \mathrm{mg}$ kloramfenikol yang dilarutkan dalam $250 \mathrm{ml}$ aquades, dan sebagai kontrol negatif menggunakan pelarut etil asetat, sedangkan untuk uji aktivitas antijamur pembuatan kontrol positif yaitu $250 \mathrm{mg}$ ketoconazole dilarutkan dalam $250 \mathrm{ml}$ akuades, dan sebagai kontrol negatif menggunakan pelarut etil asetat.

\section{Uji Aktifitas Antibakteri dan Antijamur Isolat Murni Jamur Simbion}

Pengujian dilakukan dengan konsentrasi ekstrak kasar jamur simbion 100 mg/ml, kloramfenikol, kotozonasole dan etil asetat, akan diambil masing-masing $50 \mu \mathrm{ll}$ menggunakan mikropipet yang ditotolkon pada kertas cakram berukuran $6 \mathrm{~mm}$ dengan daya serap $100 \mu \mathrm{l}$ tiap kertas cakram dimasukkan ke dalam wadah steril yang telah diberi tanda (Wikler et al., 2009).

\section{Pengamatan dan Pengukuran}

Pengamatan dilakukan setelah $1 \times 24$ jam masa inkubasi. Hasil data pengukuran yang diperoleh berupa diameter zona bening dari ekstrak jamur diukur menggunakan mistar dan dibandingkan dengan zona bening kontrol positif.

\section{HASIL DAN PEMBAHASAN}

Sampel ascidian yang diperoleh saat sampling kemudian diidentifikasi dengan mengamati morfologinya dan dibantu dengan buku pedoman Colin dan Arneson (1995). Hasil identifikasi diketahui bahwa ascidian tersebut merupakan spesies Eudistoma sp. Ciri-ciri ascidian Eudistoma sp. adalah berbentuk tebal, berwarna cokelat, dan berbintik-bintik. Ciri-ciri tersebut sesuai dengan sampel ascidian yang diperoleh dari perairan Pangalisang, Bunaken. 


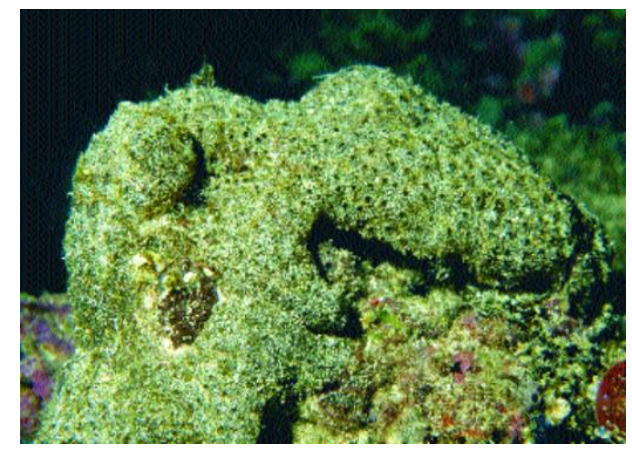

Gambar 1. Ascidian Eudistoma sp.

\section{Isolasi dan Kultur Jamur Simbion Ascidian Eudistoma sp.}

Setelah didisolasi dan diinkubasi selama $2 \times 24$ jam, pada bagian sekitar sampel terlihat munculnya bercak berwarna putih. Hal ini menandakan adanya pertumbuhan dari jamur yang bersimbiosis dengan ascidian Eudistoma sp. Jamur yang tumbuh tersebut kemudian langsung dikultur dengan tujuan untuk mendapatkan isolat jamur yang murni. Isolat jamur dikultur sebanyak dua kali sehingga didapatkan isolat jamur yang murni.

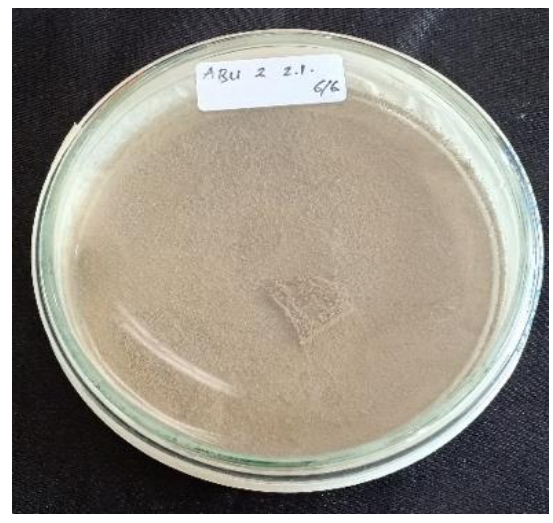

Gambar 2. Isolat Murni Jamur Simbion Eudistoma sp. (ABU2 2 .1.)

Isolat murni yang diperoleh (ABU2 2.1.) kemudian isolat tersebut diidentifikasi DNA-nya untuk mengetahui jenis jamur apa yang bersimbion dengan ascidian Eudistoma sp. Jamur simbion diidentifikasi secara molekuler di Lab. Genetika Science Jakarta, didapatkan hasil bahwa jamur yang bersimbion dengan Eudistoma sp. 5,8s ribosomal RNA gene adalah jamur Aspergillus flavus dengan keakuratan 100 persen. Aspergillus flavus adalah salah satu eukariota jamur paling umum ditemui. Aspergillus flavus dapat memproduksi aflatoksin. Aflatoksin adalah toksin (racun) yang dapat menyebabkan pertumbuhan ikan akan terganggu, juga dapat menyebabkan aspergillosis pada manusia dan hewan, dan sebagai patogen oportunistik hewan dan tumbuhan (Ramirez-Camejo et al., 2012).

\section{Eksraksi Jamur Simbion Ascidian}

Isolat jamur yang telah dikultur pada media nasi kemudian dimaserasi menggunakan etil asetat sebanyak $3 \times 100$ $\mathrm{ml}$. kemudian dievaporasi menggunakan alat Rotary vacuum evaporator.

\section{Pengujian Antibakteri dan Antijamur dari Eksrak Kasar Isolat Murni Jamur Simbion Ascidian}

Aktivitas antibakteri diamati dengan adanya zona hambat pada sekitar kertas cakram. Pengamatan dan pengukuran zona hambat menggunakan mistar dilakukan pada media mikroorganisme uji E. coli, $S$. aureus, dan $C$. albicans. Pengamatan hasil uji aktivitas antibakteri dilakukan 2x24 jam untuk mengetahui efek antimikroba yang terjadi pada masing-masing isolat jamur.

Berikut hasil pengamatan 1x24 jam uji aktivitas antibakteri dan. Hasilnya pada media bakteri E. coli (Gambar 3 dan Tabel 1). Ekstrak isolat jamur dan kontrol positif menunjukkan adanya zona hambat sebesar $10 \mathrm{~mm}$ dan kontrol positif sebesar $28,5 \mathrm{~mm}$.

Pada media bakteri $S$. aureus (Gambar 3 dan Tabel 1) ekstrak isolat jamur dan kontrol positif menunjukkan adanya zona hambat sebesar $19 \mathrm{~mm}$, kontrol positif sebesar 25,5 mm. Pada media jamur $C$. albicans hanya ekstrak isolat jamur yang menunjukkan adanya zona hambat sebesar $13,5 \mathrm{~mm}$.

Hasil pengamatan 2x24 jam uji aktivitas antibakteri dan antijamur pada media bakteri E. coli (Gambar 4 dan Tabel 1) hanya ekstrak isolat jamur yang 
menunjukkan adanya zona hambat sebesar 7,5 $\mathrm{mm}$.

Pada media bakteri $S$. aureus (Gambar 4 dan Tabel 1) ekstrak isolat jamur menunjukkan adanya zona hambat sebesar $16 \mathrm{~mm}$, dan kontrol positif sebesar $23,5 \mathrm{~mm}$. Dan pada media jamur $C$. albicans hanya ekstrak isolat jamur yang menunjukkan adanya zona hambat sebesar $13,5 \mathrm{~mm}$.
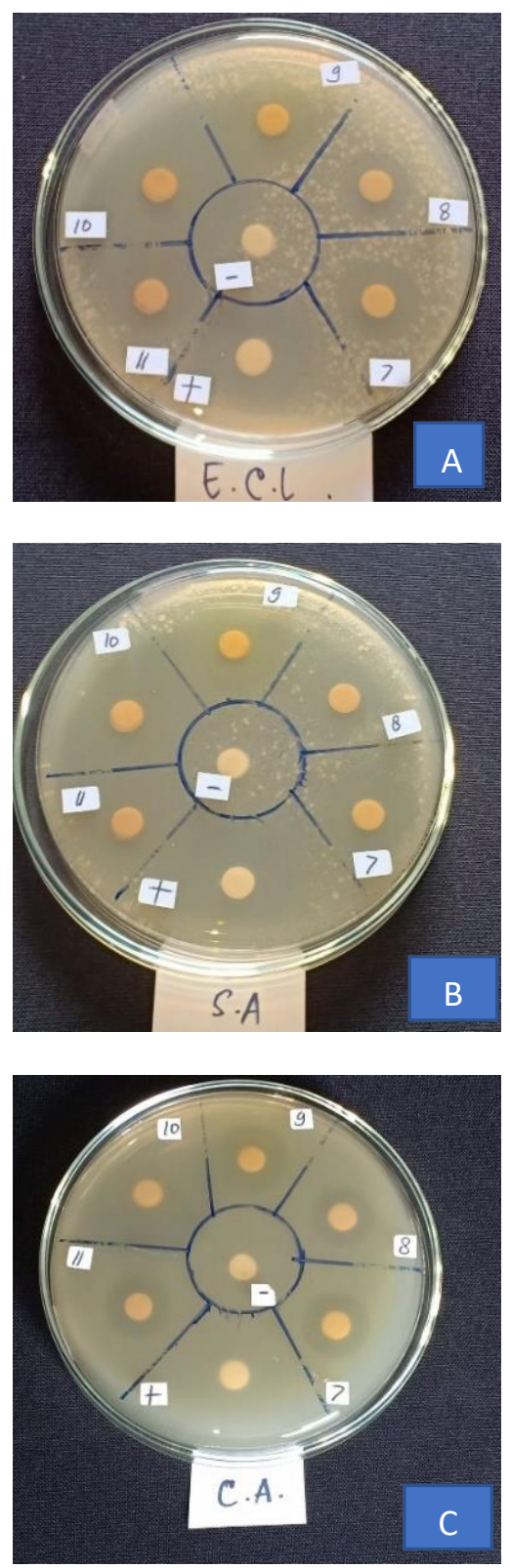

Gambar 3. A, B, C Hasil uji aktivitas antibakteri dan antijamur pengamatan $1 \times 24$ jam pada media mikrooganisme uji $E$. coli, $S$. aureus dan $C$ albicans
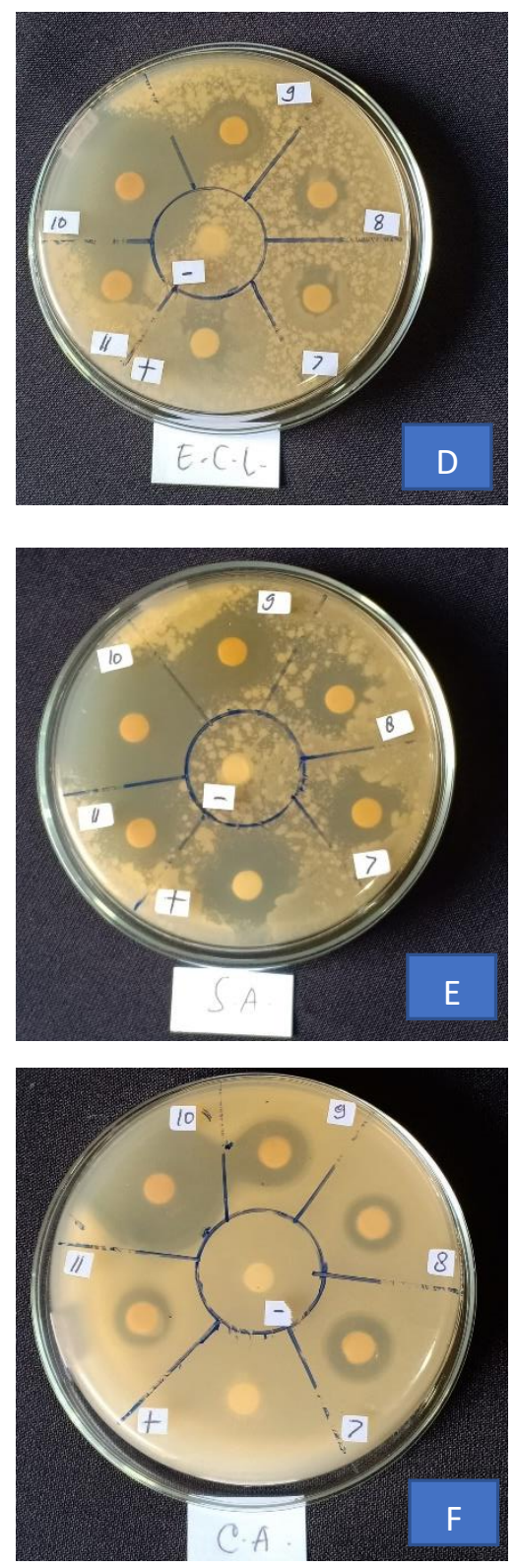

Gambar 4. D, E, F Hasil uji aktivitas antibakteri dan antijamur pengamatan 2x24 jam pada media mikrooganisme uji $E$. coli, $S$. aureus dan $C$. albicans. 
Tabel 1. Hasil Pengukuran Diameter Zona Hambat Dari Isolat Jamur Simbion Fraksi Etil Asetat Terhadap Bakteri Escherichia coli, Staphylococcus aureus dan Jamur Candida albicans

\begin{tabular}{|c|c|c|}
\hline & \multicolumn{2}{|c|}{ Isolat ABU2 2.1. (Zona hambat mm) } \\
\hline \multirow[t]{2}{*}{ Mikroorganisme Uji } & & \\
\hline & Pengamatan 1x24 Jam & Pengamatan $2 \times 24$ jam \\
\hline E. coli & 10 & 7,5 \\
\hline S. aureus & 19 & 16 \\
\hline C. albicans & 13,5 & 13,5 \\
\hline \multicolumn{3}{|c|}{ Kontrol } \\
\hline \multicolumn{3}{|c|}{ Bakteri Uji E. coli } \\
\hline Kloramfenikol (+) & 28,5 & - \\
\hline Etil Asetat (-) & - & - \\
\hline \multicolumn{3}{|c|}{ Bakteri Uji S. aureus } \\
\hline Kloramfenikol (+) & 25,5 & 23,5 \\
\hline Etil Asetat (-) & - & - \\
\hline \multicolumn{3}{|c|}{ Jamur uji C. albicans } \\
\hline Ketoconazole (+) & - & - \\
\hline Etil Asetat (-) & - & - \\
\hline
\end{tabular}


Menurut Davis dan Stout (1971) penggolongan kriteria kekuatan suatu bahan antibakteri, yakni diameter zona hambat 5 $\mathrm{mm}$ atau kurang dikategorikan lemah, dan zona hambat 5-10 $\mathrm{mm}$ dikategorikan sedang, sedangkan diameter zona hambat 10-20 mm dikategorikan kuat dan bahkan yang melebihi dari $20 \mathrm{~mm}$ dikategorikan sangat kuat.

Dari Tabel 1 pada pengamatan 1x24 jam ditunjukkan hasil yaitu bakteri $E$. coli menghasilkan penghambatan sebesar 10 $\mathrm{mm}$. Pada bakteri $S$. aureus menghasilkan penghambatan sebesar $19 \mathrm{~mm}$. Pada jamur C. albicans menghasilkan penghambatan sebesar 13,5 mm. Dari hasil uji aktivitas yang diperoleh maka diketahui bahwa isolat $8 /$ ABU2 2.1. pada pengamatan 1x24 jam memiliki aktivitas antimikroba yang tergolong kuat.

Dari Tabel 1 pada pengamatan 2x24 jam menunjukkan hasil yang berbeda pada bakteri $E$. coli dan bakteri $S$. aureus dibandingkan dengan pengamatan pada $1 \times 24$ jam, sementara pada jamur $C$. albicans tetap sama. Pada bakteri $E$. coli menghasilkan penghambatan sebesar 7,5 $\mathrm{mm}$. Pada bakteri $S$. aureus menghasilkan penghambatan sebesar $16 \mathrm{~mm}$. Pada jamur C. albicans menghasilkan penghambatan sebesar $13,5 \mathrm{~mm}$. Dari hasil uji aktivitas yang diperoleh maka diketahui bahwa isolat 8 / ABU2 2.1. pada pengamatan 2x24 jam memiliki aktivitas antimikroba yang tergolong kuat dan sedang.

Pada penelitian ini, isolat jamur simbion dari Eudistoma sp. menunjukkan adanya bioaktivitas yang berpotensi membunuh bakteri $E$. coli, $S$. aureus, dan jamur C. albicans. Ini dikarenakan jamur Aspergillus flavus dapat memproduksi aflatoksin (Ramirez-Camejo et al., 2012; Richard dan Payne 2003), dapat berkolonisasi di berbagai macam substrat, dan memiliki toleransi terhadap suhu dan salinitas yang tinggi (Hedayati et al., 2007; Mellon et al., 2007; Zuluaga-Montero et al., 2010). Dalam penelitian ini tampak bahwa kloramfenikol lebih efisien dalam menghambat pertumbuhan bakteri $S$. aureus dibandingkan dengan bakteri $E$. coli. Kontrol negatif berfungsi untuk memperlihatkan apakah etil asetat berpengaruh pada isolat atau tidak. Dalam penelitian ini, kontrol negatif tidak menunjukkan adanya zona hambat terhadap bakteri E. coli, S. aureus, dan jamur $C$. albicans.

Senyawa antibakteri dapat digolongkan juga sebagai spektrum luas dan spektrum sempit. Spektrum luas artinya senyawa tersebut bekerja aktif terhadap banyak jenis bakteri baik bakteri gram positif dan bakteri gram negatif. Sedangkan spektrum sempit artinya suatu senyawa bekerja aktif hanya terhadap satu golongan bakteri saja baik hanya pada bakteri gram positif ataupun hanya pada bakteri gram negatif (WHO, 2014). Dari beberapa penelitian yang telah dilakukan sebelumnya (Sumilat et al., 2014; Wewengkang et al., 2014; Sumilat et al., 2018), menyatakan bahwa ascidian Eudistoma sp. menghasilkan senyawa bioaktif yang mampu menghambat pertumbuhan mikroorganisme. Pada penelitian ini menunjukkan bahwa senyawa antimikroba ascidian Eudistoma sp. termasuk berspektrum luas dikarenakan kemampuannya menghambat bakteri gram positif dan gram negatif. Selain itu, senyawa antimikroba ascidian Eudistoma sp. juga mampu menghambat pertumbuhan jamur dari $C$. albicans.

Hal ini menunjukkan bahwa di lingkungan tempat hidupnya ascidian memproduksi senyawa antimikroba dalam bentuk metabolit sekunder untuk melawan semua ancaman yang dihadapinya Hasil penelitian yang menunjukkan bahwa senyawa antimikroba dari jamur simbion ascidian termasuk dalam golongan lemah, sedang, dan kuat merupakan petunjuk mengenai seberapa banyak energi yang dikeluarkan sehingga dapat menghasilkan senyawa antimikroba. Selain itu, tekanan lingkungannya juga berpengaruh dalam hal produksi metabolit sekunder antimikroba dari jamur simbion ascidian Eudistoma sp. apabila tekanan lingkungannya relatif rendah maka senyawa yang akan dihasilkan juga pasti sedikit. Kemudian apabila tekanan lingkungannya relatif tinggi maka senyawa 
yang dihasilkan akan banyak (RamirezCamejo et al., 2012).

\section{KESIMPULAN}

Berdasarkan hasil penelitian yang dilakukan, maka dapat disimpulkan bahwa isolat jamur ABU2 2.1. yang bersimbion dengan Eudistoma sp. 5,8s ribosomal RNA gene adalah jamur Aspergillus flavus dengan keakuratan 100 persen. Hasil uji aktivitas antibakteri dan antijamur ekstrak jamur simbion isolat $A B U 2$ 2.1. fraksi etil asetat memiliki aktivitas antimikroba terhadap $E$. coli, S. aureus dan C. albicans. Aktivitas tertinggi dengan diameter zona hambat tertinggi yaitu pada pada pengamatan 1 $\times 24$ jam, dengan diameter zona hambat 10,00 $\mathrm{mm}$ terhadap E. coli, $19,00 \mathrm{~mm}$ terhadap $S$. aureus, dan $13,50 \mathrm{~mm}$ terhadap $C$. albicans. Senyawa antimikroba isolat ABU2 2.1. yang bersimbion dengan ascidian Eudistoma sp. pada fraksi etil asetat termasuk berspektrum luas dikarenakan kemampuannya menghambat bakteri gram positif dan gram negatif. Selain itu, isolat tersebut juga mampu menghambat pertumbuhan dari jamur $C$. albicans.

\section{DAFTAR PUSTAKA}

Ali HAJ., Tamilselvi M. 2016. Ascidians in Coastal Water: A Comprehensive Inventory of Ascidian Fauna from the Indian Cost. Springer International Publishing. Switzerland. Hal 4-30.

Chan, STS., Pearce, AN., Januario, AH., Page, MJ., Kaiser, M. McLaughlin, RJ., Harper, JL., Webb, VL., Barker, D. and Copp, BR. 2011. Anti-inflammatory and Antimalarial Meroterpenoids from the New Zealand Ascidian Aplidium scabellum. J. Org. Chem. 76 : 91519156.

Colin PL., Arneson AC. 1995. Tropical Pasific Invertebrates: A Field Guide to the Marine Invertebrates Occuring on Tropical Pasicif Coral Reefs, Seagrass Beds and Mangroves. Coral
Reef Press. Beverly Hills, California. USA. Hal 275.

Davis, WW., Stout, TR. 1971. Disc Plate Methods Of Microbiological Antibiotic Assay. Microbiology. 22: 659-665.

Donia MS., Wang B., Dunbar DC., Densai P. V., Patny A., Avery M., Hammna M. T. 2008. Mollamides B and C, Cyclic Hexapeptides from the Indonesian Tunicate Didemnum molle. J. Nat. Prod. 71: 941-945.

Hedayati MT., Pasqualotto AC., Warn PA., Bowyer P., Denning DW. 2007. Aspergillus flavus: human pathogen, allergen and mycotoxin producer. Microbiology 153: 1677-1692.

Jawetz E., Melnick JL., Adelberg EA. 2016. Medical Microbiology Edisi ke-27. McGraw Hill Education. Hal. 363.

Kjer J., Debbab A., Aly AH., Proksch P. 2010. Methods for isolation of marinederived endophytic fungi and their bioactive secondary products. Nature Protocols. 5 (3): 479-488.

Losung F., Bara RA., Angkouw ED., 2015. Isolasi Antimikroba Dari Jamur Yang Bersimbiosis Dengan Biota Laut. Jurnal LPPM Bidang Sains Dan Teknologi. 2 (2): 37-41.

Macpal Y., Warouw V., Sumilat D A., Paulus JJH., Rumampuk NDC., Kreckhof RL. 2019. Aktivitas Antibakteri Dan Anti UV Beberapa Ascidian Dari Perairan Pangalingsang Bunaken. Jurnal Pesisir dan Laut Tropis.7 (3): 273-285. Mangindaan R.E.P. dan Taroreh R.Y. 2013. Pengujian Aktivitas Larvasida dari Ekstrak Ascidian Lissoclinum pattela Terhadap Larva Nyamuk Aedes aegypti. Jurnal Pesisir dan Laut Tropis. 3(1): 13-17.

Melliawatri R. 2009. Escherichia coli dalam kehidupan manusia. Biotrends. 4: 1.

Mellon J.E., Cotty PJ., Dowd MK. 2007. Aspergillus flavus hydrolases: their roles in pathogenesis and substrate utilization. Applied Microbiology and Biotechnology 77: 497-504.

Moerid MS., Mangindaan, REP., Losung F. 2013. Uji Aktivitas Larvasida Nyamuk 
Aedes aegypti dari Beberapa Ekstrak Ascidian. Jurnal Pesisir dan Laut Tropis. 1(1):15-20.

Opa SL., Bara RA., Gerung GS., Rompas R M., Lintang RAJ., Sumilat DA. 2018. Uji Aktivitas Antibakteri Fraksi N-Heksana, Metanol Dan Air Dari Ascidian Lissoclinum sp. Jurnal Pesisir dan Laut Tropis. 1(1): 69-80.

Proksch P., Ebrada RA., Ebel R. 2002. Drugs from The Seas-Current Status and Microbiological Implications. Appl. Microbiol. Biot. $59: 125-134$.

Ramirez-Camejo LA., Zalunga-Montero A., Lazaro-Escuedro M., HernandezKendall V., Baymann P. 2012. Phylogeography of cosmopolitan fungus Aspergilluis flavus: is everything everywhere? British Micological society. 1 (16): 452-463

Reddy DRS., Audipudi AV., Reddy GD., Bhaskar CVS. 2011. Antioxidant, AntiInflammatory and Antifungal Activity of Marine Sponge Subergargoria suberosa-Derived Natural Products. International Journal of Pharm Tech. Research.3 (1): 342-348.

Richard JL., Payne GA., 2003. Mycotoxins: risks in plant, animal, and human systems. Council for Agricultural Science and Technology. Task Force Report. 139: 422-434.

Rumengan AP. 2010. Uji Larvasida Nyamuk (Aedes aegypti) dari Ascidian (Didemnum molle). Jurnal Perikanan dan Kelautan. 6(2): 83-86.

Sumilat DA., Wewengkang DS., Paruntu C P., Rumampuk NDC., Rotinsulu H., 2014. Cytotoxic Activity of Ascidians Eudistoma sp. From Mantehage Island Manado. Jurnal LPPM Bidang Sains dan Teknologi. 1(1): 1-6.

Sumilat DA., Yamazaki H., Endo K., Rotinsulu H., Wewengkang DS., Ukai K., Namikoshi M. 2017. A new biphenyl eter derivative produced by Indonesian ascidians-derived Penicillium albobiverticillium. J. Nat. Med. 71:776779.

Sumilat DA., Wewengkang DS., Rotinsulu H., Yamazaki H., Taiko O., Ukai K.,
Namikoshi M. 2018. Bioactivity of Extracts from Ascidians Collected in North Sulawesi As Seeds of MarineDerived Drugs. AACL Bioflux.11 (2): 516-512.

Wang W., Nam SJ., Lee BC., Kang H. 2008. Beta-carboline Alkaloids from A Korean Tunicate Eudistoma sp. J. Nat. Prod. 71(2): 163-169.

Warsa VC. 1994. Kokus Positif Gram. Buku Ajar Mikrobiologi Kedokteran. Fakultas Kedokteran Ul. Jakarta. Binarupa Aksara. Hal 5-22.

Wewengkang DS., Sumilat DA., Rotinsulu H. 2014. Sitotoksitas Ekstrak Kasar Ascidian dari Pulau Bunaken. Jurnal LPPM Bidang Sains dan Teknologi. 1(1): 86-89.

WHO. 2014. Antmicrobial resistance: global report on survaillance 2014. World Health Organization. Hal. 257.

Wikler MA., Cockeril FR., Bush K., Dudley MN., Eliopoulos JM., Hardy DJ., Hecht DW. 2009. Performance Standards for Antimicrobial Disk Susceptibility Tests: Approved Standard $10^{\text {th }}$ Edition. Clinical and Laboratory Standards Institute. Pennsylvania, USA. Hal. 1117.

Zuluaga-Montero A, Ramırez-Camejo L, Rauscher J, Bayman P. 2010. Marine isolates of Aspergillus flavus: denizens of the deep or lost at sea? Fungal Ecology 3:386-391. 